\title{
Prevalence of Dating Violence among Adolescents from Brazilian Public Schools of Recife/Pe - Brazil
}

\author{
Prevalência de Violência no Namoro entre Adolescentes de Escolas Públicas de Recife/Pe - Brasil \\ Prevalencia de la Violencia en el Noviazgo entre Adolescentes de Escuelas Públicas de Recife/Pe - Brasil \\ Maria Aparecida Beserra*; Maria Neto da Cruz Leitão**; Maria Isabel Domingues Fernandes***;

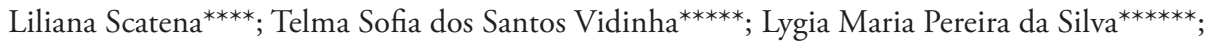 \\ Maria das Graças de Carvalho Ferriane ${ }^{* * * * * * *}$
}

\begin{abstract}
Theoretical framework: Dating violence is a serious and avoidable public health issue worldwide, which may have negative consequences in adolescents' health.

Objectives: To estimate the prevalence of dating violence in adolescence and to characterise episodes of dating violence according to socio-demographic variables.

Methodology: Cross-sectional descriptive study, with an estimated population of 4,905 students. Sample composed of 643 adolescents, of which a subset of 260 participants who had a boyfriend/girlfriend at the time of the study was extracted. The following questionnaires were used: Global School-based Student Health Survey and Violência na Escola (Violence at School). Data were analysed using the Statistical Package for the Social Sciences (SPSS), version 21.

Results: The prevalence of dating violence was $19.2 \%$. Significant associations were found between gender and the questions (victim or aggressor), with more girls being aggressors (14.3\%). After the aggression episode, $40 \%$ of adolescents felt nothing and $28 \%$ considered it normal, $40 \%$ of participants did nothing and $36 \%$ ended the relationship.

Conclusion: A naturalisation of dating violence is observed, thus prevention programs should be developed.
\end{abstract}

Keywords: Violence; adolescent; relationship; prevalence

\section{Resumo}

Enquadramento: A violência no namoro é um grave e evitável problema de saúde pública mundial que poderá trazer consequências negativas à saúde dos adolescentes.

Objetivos: Estimar a prevalência da violência no namoro na adolescência; caracterizar ocorrências de acordo com variáveis sociodemográficas. Metodologia: Estudo descritivo transversal com uma população estimada em 4.905 estudantes. Amostra constituída por 643 adolescentes, dessa foi extraído um subgrupo de 260 participantes que tinham namorado(a) na época da pesquisa. Utilizaram-se os questionários: Global Schoolbased Student Health Survey, e Violência na Escola. Os dados foram analisados através do Statistical Package for the Social Sciences (SPSS), versão 21.

Resultados: A prevalência da violência no namoro foi de $19,2 \%$. Verificaram-se associações significativas entre o sexo e as questões (vítima ou agressor), observando-se mais raparigas agressoras (14,3\%). Após a agressão, $40 \%$ respondeu que não sentiu nada e $28 \%$ achou normal, $40 \%$ afirmou não ter feito nada e 36\% terminou a relação. Conclusão: Observa-se uma naturalização da violência no namoro, pelo que seria necessário desenvolver programas de prevenção da ocorrência desse fenómeno.

Palavras-chave: Violência; adolescente; relacionamento; prevalência

\footnotetext{
* MSc., Assistant Professor, University of Pernambuco, 50670-901, Pernambuco, Brazil [mcidabeserra@ ig.com.br]. Contribution to the article: Bibliographic search; statistical evaluation; article writing. Address for correspondence: Rua Dona Uzinha Nunes, № $237 / 702,223407.006$ Boa Viagem, Recife, Pernambuco, Brazil. of Coimbra, 3046-851, Coimbra, Portugal [mneto@ @esenfc.pt]. Contribution to the article: Data analysis and

discussion.
${ }^{* * * * *}$ Ph.D., Adjunct Professor, Nursing School of Coimbra, 3046-851, Coimbra, Portugal [liliana scatena@ hotmail.com]. Contribution to the article: Data analvsis and discussion.

***** Bacharelato, Ribeirão Preto College of Nursing, University of São Paulo, 14040-902, Ribeirāo Preto, Brazil [liliana_scatena@hotmail.com..Contribution to the article: Data analysis and discussion.

******-1N, Hospital Centre of Coimbra, EPE, 3041-801, Coimbra, Portugal [telmavidinha@esenfc.pt]. Contribution to the article: Data analysis and discussion.

******** Ph.D., Adjunct Professor, Faculty of Nursing Nossa Senhora das Graças, University of Pernambuco, 50670-901, Pernambuco, Brazil llygiapera@yahoo.com.br].

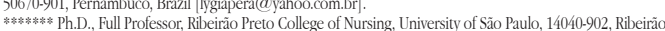
Preto, Brazil [gracacarvalho@usp.br]. Contribution to the article: Data analysis and discussion.
}

\section{Resumen}

Contexto: La violencia en el noviazgo es un problema de salud pública mundial grave y evitable que puede dar lugar a consecuencias negativas para la salud de los adolescentes.

Objetivos: Estimar la prevalencia de la violencia en el noviazgo en la adolescencia; caracterizar casos de acuerdo con variables sociodemográficas

Metodología: Estudio descriptivo transversal con una población estimada en 4.905 estudiantes. La muestra estuvo constituida por 643 adolescentes, de los cuales se extrajo un subconjunto de 260 participantes que tenían novio/a en el momento de la investigación. Para ello, se utilizaron los cuestionarios: Global School-based Student Health Survey y Violencia en la Escuela. Los datos se analizaron a través del Statistical Package for the Social Sciences (SPSS), versión 21. Resultados: La prevalencia de la violencia en el noviazgo fue del 19,2\%. Se verificaron asociaciones significativas entre el sexo y las cuestiones (víctima o agresor), y se observó que hay más chicas agresoras (14,3\%). Después de la agresión, el 40 \% respondió que no sintió nada y el 28 \% lo consideró normal; el 40 \% afirmó que no hizo nada y el 36 \% que terminó la relación.

Conclusión: Se observa una naturalización de la violencia en el noviazgo, por lo que sería necesario desarrollar programas de prevención de este fenómeno.

Palabras clave: Violencia; adolescente; prevalencia; relación

Received for publication: 13.02 .15

Accepted for publication: 14.10 .15 


\section{Introduction}

This study focuses on dating violence among adolescents in the city of Recife, Brazil. According to the World Health Organization, dating violence refers to any "behaviour in an intimate relationship that causes physical, psychological or sexual harm, including acts of physical aggression, forced intercourse, psychological abuse, and controlling behaviours" (cited by Heise \& Garcia-Moreno, 2002, p. 107), being a violation of human rights. Adolescence is defined by the World Health Organization (WHO) as the period between 10 and 19 years of age, i.e. the second decade of life (WHO, 2015). The notion of adolescence can be built based on the objective and concrete reality and therefore factors such as social class, ethnicity, gender, age and culture are important in the construction of the meaning of being an adolescent (Ozella \& Aguiar, 2008). This is a phase of life in which many of the personality characteristics and models of interpersonal relationships are defined. The Centers for Disease Control and Prevention (CDC, 2014) argues that the belief that dating violence is acceptable is one of the strongest factors for the occurrence of more violent behaviours. When naturalised and trivialised in an intimate relationship, violence exposes the young population to its consequences, which influences the need for the development of studies that contribute to the elaboration of coping and prevention strategies.

This phenomenon is becoming increasingly important worldwide, by which Minayo, Assis, e Njaine (2011) value the development of national and international studies with a view to improving the affective-sexual experiences among adolescents and preventing conjugal violence. A study conducted by Barreira, Lima, and Avanci (2013) in Brazil, with adolescents enrolled in public and private schools, aged between 15 and 19 years, identified a prevalence of physical violence of $19.9 \%$, of psychological violence of $82.8 \%$ and of both of $18.9 \%$ in dating relationships. Other studies have demonstrated that dating violence can negatively influence health throughout the lifespan. Young victims are more prone to showing symptoms of depression and anxiety, engaging in unhealthy behaviours, such as smoking and alcohol and drug use, or displaying anti-social behaviours and suicidal thoughts (Foshee, Reyes, Gottfredson, Chang, \& Ennett, 2013).
In the last decades, adolescent health has become a priority in many countries, particularly in institutions that promote research, because the construction of the lifestyle is crucial not only for adolescents, but also for the future generations (Ruzany, 2008).

Taking into account that adolescence is an important period for establishing the necessary foundations for the development of healthy relationships and the general well-being throughout the lifespan, the guarantee that adolescents and young people can enjoy relationships free of violence is an important investment in their future.

\section{Background}

Dating violence is a serious and avoidable public health issue. The scientific community has been increasingly concerned with this problem, especially due to its impact on the life and health of the victims and the importance and need to develop prevention programs. The study to this issue for the identification of its multicausality leads to possible coping mechanisms (Minayo et al., 2011). In addition to having complex causes, dating violence is the result of multiple factors: Individual, family, community and social factors. Such factors may include an aggressive or criminal behaviour, the use of alcohol or other drugs, the presence or experience of violence in childhood, the marital conflicts, the acquisition and loss of control in a relationship, and unemployment (Minayo et al., 2011).

The studies focusing on dating relationships among adolescents, although presenting a wide conceptual variation, identify a very significant and diversified prevalence of violence: 8.9\% (Barreira et al., 2013); 20\% (Basile et al., 2006); and 83.9\% (Barreira, Lima, Bigras, Njaine, \& Assi, 2014). This disparity is often attributed to the use of different methodologies and the lack of a conceptual standard (Barreira et al., 2013).

In Portugal, several studies have been developed with the aim of contributing to the analysis and discussion of the problem from the perspective of preventing this phenomenon, such as the work of Leitão et al. (2013) on the impact of gender violence on human rights and on the health and well-being of victims and families. 


\section{Research Question}

Taking into account the magnitude of violence in dating relationships and its impact on adolescent health, we decided to carry out this study with the purpose of analysing the severity of the problem. We raise the hypothesis that dating violence is part of the daily life of adolescents' relationships in several social spaces, being different for boys and girls.

Thus, this study has the following objectives: To estimate the prevalence of dating violence in adolescence; to characterise the episodes according to sociodemographic variables; and to identify the types of violence perpetrated and experienced.

\section{Methodology}

This cross-sectional and descriptive study, of epidemiological nature, which explores the phenomenon of dating violence, is part of a larger research study that aimed at analysing violence in adolescence within school settings. The population was composed of 4,905 male and female students aged between 12 and 18 years, enrolled in six state schools in the neighbourhood of Santo Amaro in the city of Recife, Pernambuco/Brazil. These state schools were chosen because this neighbourhood has a major incidence of poverty and violence, is dominated by drug trafficking and has no private schools.

To determine sample size, the following aspects were considered: the estimated population size of 4,905 students enrolled in the six state schools of the neighbourhood; the margin of error was set at 5\%; the $95 \%$ confidence that the margin of error was not exceeded; the expected percentage of $50 \%$ for each answer category, which is a value that maximised sample size. After the calculations, a sample of 643 adolescents was obtained. The research was conducted with a subgroup of 260 participants extracted from the initial sample and who had a boyfriend/girlfriend at the time of the study.

Data were collected using two self-administered questionnaires with closed-ended questions: The Global School-based Student Health Survey (WHO, 2012) for the socio-economic and demographic characterisation of students; and the Violência na Escola (Violence at School) (Freire, Simão \& Ferreira, 2006), validated for the Brazilian population, to which seven questions were added relating to dating violence. Data were collected between July 7 and September 5, 2014. The results were analysed through absolute and percentage distribution. The association between two categorical variables was assessed using the Chi-square test or the Fisher's exact test when it is not possible to use the Chi-square test. The degree of association was assessed by calculating the odds ratio $(\mathrm{OR})$ and the respective confidence interval (CI). The margin of error used in the decisions of the statistical tests was 5\% and 95\% CIs were obtained. The SPSS software, version 21, was used for all statistical analyses in this study.

The research complied with the ethical aspects and the legal implications of Resolution 196/96 of the National Health Council/Ministry of Health of Brazil, preserving the anonymity of the subjects involved. Data were only collected after the approval of the Research Ethics Committee of the University of Pernambuco, under protocol no. 705.598 in 01/07/2014, and after the Free and Informed Consent Form was signed by the adolescents and their parents or guardians.

\section{Results}

A total of 643 adolescents participated in the study, whose most important sociodemographic characteristics were the following: $56.5 \%$ were aged between 15 and 18 years and the remaining between 12 and 14 years; $64.2 \%$ were female and 93.6\% were single; most of them considered themselves to be non-Caucasian (82.3\%), 70.6\% considered themselves to be "pardo"/ "mulato"/ "moreno"; more than half of the sample (54.1\%) had secondary education, whereas the other participants had basic education. In relation to the questions "Do you work?", "Do you live with your father?", "Do you live with your mother?" and "In what region do you live?", we found that most of them did not work (87.9\%); $56.8 \%$ lived with their father and $89.7 \%$ with their mother; and 95.5\% lived in the urban region. A little over half (52.3\%) of the participants' mothers had between 8 and 11 years of schooling, and $28.9 \%$ had less than 8 years of schooling.

Of the 643 adolescent participants, 260 (40.4\%) had a boyfriend/girlfriend and of these: 19.2\% had already experienced violence by a boyfriend/ 
girlfriend and in this subgroup (Table 1) the most frequent type of violence was verbal/moral violence (60.4\%), followed by physical violence (28.3\%), with the condition that the same participant could have experienced more than one type of violence. In this sample, $22.7 \%$ reported having already been abusive to a boyfriend/girlfriend, with a higher prevalence of verbal/moral violence (60.3\%) and physical violence (35.3\%).
Of the 50 adolescents who had experienced violence by a boyfriend/girlfriend, the majority (26.7\%) of them reported not having developed any feelings about the aggression; $18.7 \%$ considered it to be normal; and $18.7 \%$ to $16.0 \%$ of them reported feelings of anger, revenge and disappointment. In relation to the behaviour after the violence episode, most of them (40.0\%) did nothing (request for support) and 36.0\% reported having ended the relationship.

\section{Table 1}

Distribution of the adolescents who participated in the study and had a boyfriend/girlfriend according to the type of dating violence experienced and perpetrated

\begin{tabular}{|c|c|c|}
\hline VARIABLE & $N$ & $\%$ \\
\hline \multicolumn{3}{|c|}{ Did your boyfriend/girlffriend ever hurt you? } \\
\hline Yes & 50 & 19.2 \\
\hline No & 210 & 80.8 \\
\hline TOTAL & 260 & 100.0 \\
\hline \multicolumn{3}{|l|}{ What type of aggression? ${ }^{(1)}$} \\
\hline Verbal/Moral & 32 & 60.4 \\
\hline Physical & 15 & 28.3 \\
\hline Sexual & 2 & 3.8 \\
\hline Threat & 4 & 7.5 \\
\hline TOTAL & 53 & 100.0 \\
\hline \multicolumn{3}{|c|}{ Have you ever hurt your boyfriend/girlfriend? } \\
\hline Yes & 59 & 22.7 \\
\hline No & 201 & 77.3 \\
\hline TOTAL & 260 & 100.0 \\
\hline \multicolumn{3}{|c|}{ If yes, what type of aggression? } \\
\hline Verbal/Moral & 41 & 60.3 \\
\hline Physical & 24 & 35.3 \\
\hline Sexual & 1 & 1.5 \\
\hline Threat & 2 & 2.9 \\
\hline TOTAL & 59 & 100.0 \\
\hline \multicolumn{3}{|c|}{ How did you feel after the aggression?(1) } \\
\hline Anger & 13 & 17.3 \\
\hline Wanted to get revenge & 14 & 18.7 \\
\hline Fear & 2 & 2.6 \\
\hline Disappointment & 12 & 16.0 \\
\hline Felt nothing & 20 & 26.7 \\
\hline Considered it normal & 14 & 18.7 \\
\hline TOTAL & 75 & 100.0 \\
\hline \multicolumn{3}{|c|}{ What did you do after the aggression?(1) } \\
\hline Ended the relationship & 18 & 36.0 \\
\hline Reported to the police & 2 & 4.0 \\
\hline Told the parents & 7 & 14.0 \\
\hline Told the teacher & 3 & 6.0 \\
\hline Did nothing & 20 & 40.0 \\
\hline TOTAL & 50 & 100.0 \\
\hline
\end{tabular}


Tables 2 and 3 show the results of the association between each of the variables on the aggression by the boyfriend/girlfriend, the age range, and the gender in the group of 260 participants who had a boyfriend/ girlfriend at the time of data collection.

Table 2 shows that $11.9 \%$ of the respondents are aggressors, $10.8 \%$ are victims and aggressors, and $8.5 \%$ are victims. The end of the dating relationship was more common among young people aged between 12 and 14 years (47.6\%). However, there was no significant association between the participants' age range and dating violence.

Table 2

Analysis of the type of aggression experienced and perpetrated by the boyfriend/girlfriend according to the age range

\begin{tabular}{|c|c|c|c|c|c|c|c|c|}
\hline \multirow{3}{*}{ VARIABLE } & \multicolumn{4}{|c|}{ AGE RANGE } & \multirow{2}{*}{\multicolumn{2}{|c|}{$\begin{array}{l}\text { GROUP TOTAL } \\
\quad p \text { value }\end{array}$}} & \multirow{3}{*}{$\mathrm{OR}[95 \% \mathrm{CI}]$} & \\
\hline & \multicolumn{2}{|c|}{12 to 14} & \multicolumn{2}{|c|}{15 to 18} & & & & \\
\hline & $n$ & $\%$ & $n$ & $\%$ & \multicolumn{2}{|c|}{$\begin{array}{c}p \text { value } \\
n \quad \%\end{array}$} & & \\
\hline TOTAL & 89 & 100.0 & 171 & 100.0 & 260 & 100.0 & & \\
\hline \multicolumn{9}{|l|}{ Aggressor/Victim of boyfriend/girlfriend } \\
\hline Did not experience/ Did not perpetrate & 57 & 64.0 & 122 & 71.3 & 179 & 68.8 & $p^{(1)}=0.207$ & 1.00 \\
\hline Victim & 12 & 13.5 & 10 & 5.8 & 22 & 8.5 & & $2.57[1.05$ to 6.29$]$ \\
\hline Aggressor & 11 & 12.4 & 20 & 11.7 & 31 & 11.9 & & $1.18[0.53$ to 2.62$]$ \\
\hline Victim/ Aggressor & 9 & 10.1 & 19 & 11.1 & 28 & 10.8 & & $1.01[0.43$ to 2.38$]$ \\
\hline \multicolumn{9}{|l|}{ Aggression experienced } \\
\hline \multicolumn{9}{|l|}{ Verbal/Moral } \\
\hline Yes & 11 & 12.4 & 21 & 12.3 & 32 & 12.3 & $p^{(1)}=0.985$ & 1.01 [0.46 to 2.20$]$ \\
\hline No & 78 & 87.6 & 150 & 87.7 & 228 & 87.7 & & 1.00 \\
\hline \multicolumn{9}{|l|}{ Physical } \\
\hline Yes & 7 & 7.9 & 8 & 4.7 & 15 & 5.8 & $p^{(1)}=0.296$ & 1.74 [0.61 to 4.96$]$ \\
\hline No & 82 & 92.1 & 163 & 95.3 & 245 & 94.2 & & 1.00 \\
\hline \multicolumn{9}{|l|}{ Aggression perpetrated } \\
\hline Yes & 14 & 15.7 & 27 & 15.8 & 41 & 15.8 & $p^{(1)}=0.990$ & 1.00 \\
\hline No & 75 & 84.3 & 144 & 84.2 & 219 & 84.2 & & $1.00[0.50$ to 2.03$]$ \\
\hline \multicolumn{9}{|l|}{ Physical } \\
\hline Yes & 8 & 9.0 & 16 & 9.4 & 24 & 9.2 & $p^{(1)}=0.923$ & 1.00 \\
\hline No & 81 & 91.0 & 155 & 90.6 & 236 & 90.8 & & $1.05[0.43$ to 2.55$]$ \\
\hline \multicolumn{9}{|l|}{ What did you feel after the aggression? } \\
\hline \multicolumn{9}{|l|}{ Anger } \\
\hline Yes & 6 & 6.7 & 7 & 4.1 & 13 & 5.0 & $p^{(2)}=0.378$ & $1.69[0.55$ to 5.20$]$ \\
\hline No & 83 & 93.3 & 164 & 95.9 & 247 & 95.0 & & 1.00 \\
\hline \multicolumn{9}{|l|}{ Wanted to get revenge } \\
\hline Yes & 6 & 6.7 & 8 & 4.7 & 14 & 5.4 & $p^{(1)}=0.565$ & $1.47[0.49$ to 4.39$]$ \\
\hline No & 83 & 93.3 & 163 & 95.3 & 246 & 94.6 & & 1.00 \\
\hline \multicolumn{9}{|l|}{ Disappointment } \\
\hline Yes & 3 & 3.4 & 9 & 5.3 & 12 & 4.6 & $p^{(2)}=0.756$ & 1.00 \\
\hline No & 86 & 96.6 & 162 & 94.7 & 248 & 95.4 & & $1.59[0.42$ to 6.04$]$ \\
\hline \multicolumn{9}{|l|}{ Felt nothing } \\
\hline Yes & 6 & 6.7 & 14 & 8.2 & 20 & 7.7 & $p^{(1)}=0.678$ & 1.00 \\
\hline No & 83 & 93.3 & 157 & 91.8 & 240 & 92.3 & & 1.23 [0.46 to 3.33$]$ \\
\hline \multicolumn{9}{|l|}{ Considered it normal } \\
\hline Yes & 7 & 7.9 & 7 & 4.1 & 14 & 5.4 & $p^{(2)}=0.248$ & $2.00[0.68$ to 5.89$]$ \\
\hline No & 82 & 92.1 & 164 & 95.9 & 246 & 94.6 & & 1.00 \\
\hline \multicolumn{9}{|l|}{ Attitude after the aggression } \\
\hline Ended the relationship & 10 & 47.6 & 8 & 27.6 & 18 & 36 & $p^{(2)}=0.605$ & $* *$ \\
\hline Reported to the police & - & - & 2 & 6.9 & 2 & 4.0 & & $* *$ \\
\hline Told the parents & 3 & 14.3 & 4 & 13.8 & 7 & 14.0 & & $* *$ \\
\hline Told the teacher & 1 & 4.8 & 2 & 6.9 & 3 & 6.0 & & $* *$ \\
\hline Did nothing & 7 & 33.3 & 13 & 44.8 & 20 & 40.0 & & $* *$ \\
\hline
\end{tabular}

(*): Significant difference set at 5.0\%; (**): Not calculated due to null frequency; (1): Using Pearson's chi-square test; (2): Using Fisher's exact test. 
Table 3 shows the significant differences: Between gender and the position of the respondent towards the situation of violence - victim, aggressor, both, or did not experience aggression; between gender and physical or verbal/moral aggression experienced or perpetrated; and between gender and what he/she felt when attacked. The following aspects stand out for these variables: The percentage of those who did not experience aggression and of those who were aggressors was higher in females $(72.0 \%$ and $14.3 \%$, respectively) than in males $(63.0 \%$ and $7.6 \%$, respectively); the percentage of those who were victims was higher in males (18.5\%); the percentage of those who experienced verbal/moral aggression was higher in males (19.6\%); the percentage of those who physically assaulted the partners was higher among female adolescents (11.9\%); and the percentage of those who wanted to get revenge was higher in males (9.8\%). The end of the dating relationship was the most common behaviour and its prevalence was higher among females (39.1\%). As regards the percentage of those who did nothing after the victimisation, a quite significant percentage was found both in males (40.7\%) and in females (39.1\%).

Table 3

Analysis of the type of aggression experienced and perpetrated by the boyfriend/girlfriend according to gender

\begin{tabular}{|c|c|c|c|c|c|c|c|c|}
\hline \multirow{3}{*}{ VARIABLE } & \multicolumn{4}{|c|}{ GENDER } & \multirow{2}{*}{\multicolumn{2}{|c|}{$\begin{array}{c}\text { GROUP TOTAL } \\
\text { p value }\end{array}$}} & \multirow{3}{*}{$\mathrm{OR}[95 \% \mathrm{CI}]$} & \\
\hline & \multicolumn{2}{|c|}{ MALE } & \multicolumn{2}{|c|}{ FEMALE } & & & & \\
\hline & $n$ & $\%$ & $n$ & $\%$ & $n$ & $\%$ & & \\
\hline TOTAL & 92 & 100.0 & 168 & 100.0 & 260 & 100.0 & & \\
\hline Aggressor/Victim of boyfriend/girlfriend & & & & & & & & \\
\hline Did not experience/ Did not perpetrate & 58 & 63.0 & 121 & 72.0 & 179 & 68.8 & $p^{(1)}<0.001^{*}$ & 1.00 \\
\hline Victim & 17 & 18.5 & 5 & 3.0 & 22 & 8.5 & & $7.09[2.49$ to 20.17$]$ \\
\hline Aggressor & 7 & 7.6 & 24 & 14.3 & 31 & 11.9 & & $0.61[0.25$ to 1.49$]$ \\
\hline Victim/ Aggressor & 10 & 10.9 & 18 & 10.7 & 28 & 10.8 & & $1.16[0.50$ to 2.67$]$ \\
\hline Aggression experienced & & & & & & & & \\
\hline Verbal/Moral & & & & & & & & \\
\hline Yes & 18 & 19.6 & 14 & 8.3 & 32 & 12.3 & $p^{(1)}=0.008^{*}$ & 2.68 [1.26 to 5.67$]$ \\
\hline No & 74 & 80.4 & 154 & 91.7 & 228 & 87.7 & & 1.00 \\
\hline Physical & & & & & & & & \\
\hline Yes & 6 & 6.5 & 9 & 5.4 & 15 & 5.8 & $p^{(1)}=0.700$ & $1.23[0.42$ to 3.58$]$ \\
\hline No & 86 & 93.5 & 159 & 94.6 & 245 & 94.2 & & 1.00 \\
\hline Aggression perpetrated & & & & & & & & \\
\hline Verbal/Moral & & & & & & & & \\
\hline Yes & 13 & 14.1 & 28 & 16.7 & 41 & 15.8 & $p^{(1)}=0.592$ & 1.00 \\
\hline No & 79 & 85.9 & 140 & 83.3 & 219 & 84.2 & & $1.22[0.60$ to 2.48$]$ \\
\hline Physical & & & & & & & & \\
\hline Yes & 4 & 4.3 & 20 & 11.9 & 24 & 9.2 & $p^{(1)}=0.044^{*}$ & 1.00 \\
\hline No & 88 & 95.7 & 148 & 88.1 & 236 & 90.8 & & $2.97[0.98$ to 8.98$]$ \\
\hline What did you feel after the aggression? & & & & & & & & \\
\hline Anger & & & & & & & & \\
\hline Yes & 6 & 6.5 & 7 & 4.2 & 13 & 5.0 & $p^{(2)}=0.392$ & $1.60[0.52$ to 4.92$]$ \\
\hline No & 86 & 93.5 & 161 & 95.8 & 247 & 95.0 & & 1.00 \\
\hline Wanted get revenge & & & & & & & & \\
\hline Yes & 9 & 9.8 & 5 & 3.0 & 14 & 5.4 & $p^{(2)}=0.040^{*}$ & $3.53[1.15$ to 10.89$]$ \\
\hline No & 83 & 90.2 & 163 & 97.0 & 246 & 94.6 & & 1.00 \\
\hline Disappointment & & & & & & & & \\
\hline Yes & 6 & 6.5 & 6 & 3.6 & 12 & 4.6 & $p^{(2)}=0.355$ & $1.88[0.59$ to 6.02$]$ \\
\hline No & 86 & 93.5 & 162 & 96.4 & 248 & 95.4 & & 1.00 \\
\hline Felt nothing & & & & & & & & \\
\hline Yes & 7 & 7.6 & 13 & 7.7 & 20 & 7.7 & $p^{(1)}=0.970$ & 1.00 \\
\hline No & 85 & 92.4 & 155 & 92.3 & 240 & 92.3 & & $1.02[0.39$ to 2.65$]$ \\
\hline
\end{tabular}




$\begin{array}{lcccccccc}\text { Considered it normal } & 7 & 7.6 & 7 & 4.2 & 14 & 5.4 & p^{(2)}=0.260 & 1.89[0.64 \text { to } 5.58] \\ \quad \text { Yes } & 85 & 92.4 & 161 & 95.8 & 246 & 94.6 & 1.00 \\ \text { No } & & & & & & & \\ \text { Attitude after the aggression } & 9 & 33.3 & 9 & 39.1 & 18 & 36 & p^{(2)}=1.000 & * * \\ \text { Ended the relationship } & 1 & 3.7 & 1 & 4.3 & 2 & 4.0 & * * \\ \text { Reported to the police } & 4 & 14.8 & 3 & 13.0 & 7 & 14.0 & * * \\ \text { Told the parents } & 2 & 7.4 & 1 & 4.3 & 3 & 6.0 & * * \\ \text { Told the teacher } & 11 & 40.7 & 9 & 39.1 & 20 & 40.0 & * * \\ \text { Did nothing } & & & & & & \end{array}$

(*): Significant difference set at 5.0\%; (**): Not calculated due to very low frequencies; (1): Using Pearson's chi-square test; (2): Using Fisher's exact test.

\section{Discussion}

With regard to the results on the perpetration and victimisation of dating violence, we observed that $19.2 \%$ of the adolescents reported having already experienced violence by a boyfriend/girlfriend. The prevalence found is relatively similar to the one found in other national and international studies developed by several authors. At an international level, the estimated prevalence is between 21.8\% and 60\% (Haynie et al., 2013; Straus, 2004). Basile et al. (2006), in a study with 15,214 American students from 158 secondary schools, found that $8.9 \%$ of them had experienced dating violence, being that 8.9\% were boys and $8.7 \%$ were girls. In Brazil, a study with a sample of 455 university students from São Paulo found a prevalence of $21.1 \%$ of intimate partner violence (Aldrighi, 2004). In the city of Recife, Pernambuco, Barreira et al. (2013), working with a significant sample of adolescents from public and private schools, found that 19.9\% of the adolescents had perpetrated physical violence against their intimate partners. Oliveira, Assis, Njaine, and Carvalhaes (2011), in a study with young people from public and private schools of capital cities from ten Brazilian states, identified a prevalence of victimisation and perpetration well above the national and international values: $86.9 \%$ as victims and $86.8 \%$ as perpetrators. The bidirectionality of violence or reciprocal practice between adolescent partners was also observed in the study of Minayo et al. (2011).

Although some studies more often indicate females as victims, in this study we found a greater prevalence of victimisation in males (18.5\%) and of aggression in females (14.3\%). These results corroborate those obtained by Oliveira, Assis, Njaine, and Pires (2014), who found a higher frequency of perpetration of dating violence or in "stay" relationships by female adolescents (18.4\%). Straus and Gozjolko (2014) emphasised that, although some studies confirm that the female gender is more often involved in acts of violence, the adverse effects on the victims are much more significant when perpetrated by males and may cause more injuries (both physical and psychological), more deaths and more fear.

In relation to the nature of dating violence, the percentage of those who experienced verbal/moral violence was higher in males (19.6\%). According to Oliveira et al. (2011), verbal violence is the most common type of violence in the relationships between young people and the authors emphasise that its high frequency contributes to its trivialisation, because it is common and acceptable in some situations. Barreira et al. (2013) also found a prevalence of perpetrated psychological violence in $82.8 \%$ of the sample participants: $80.6 \%$ in females and $85.6 \%$ in males. In a study conducted by Bonomi, Anderson, Nemeth, Rivara, and Buettner (2014), 28.4\% of the girls and $19.3 \%$ of the boys experienced physical and/or sexual violence; and the psychological violence related to yelling, insulting and threatening was more prevalent among females (47.6\%) than among males (40.7\%).

We also found that physical violence occupies the second position, with $9.2 \%$. The percentage of those who perpetrated physical violence was higher among female adolescents (11.9\%), corroborating the results of other studies such as the one by Oliveira et al. (2011), with 16.8\% for males and 28.5\% for females, and Barreira et al. (2013), with 21.8\% for females and $17.4 \%$ for males.

In a study conducted with young university students from 32 different countries, including Brazil, 17\% to $49 \%$ of them reported having been physically assaulted by their partner in the last year, with an average of 
$29 \%$, whereas the prevalence of more severe physical aggression, such as punching, strangling and attacking with weapons, was, on average, of 10\% to 15\% (Straus, 2004).

Sexual violence was rarely reported by both boys and girls, both experienced (4.0\%) and perpetrated (1.7\%) violence. In the study by Oliveira et al. (2014), a very significant percentage of this type of violence was identified in both males and females, with $43.8 \%$ experiencing and $38.9 \%$ perpetrating some form of sexual violence in intimate relationships, including kissing when the partner does not want; touching sexually without the partner's consent and forcing the partner to have sexual intercourse; and threatening to try to have sexual intercourse. It should be underlined that adolescence is a phase of discovery, during which most adolescents start dating and exploring their sexuality.

The naturalisation of dating violence emerges in the questions related to the feelings of the adolescents and in the decision made after the aggression. A very significant percentage of adolescents answered that they felt nothing (40.0\%) and found it normal (28.0\%). As for the decision made after the aggression, 40.0\% did nothing and 36.0\% ended the relationship. Oliveira et al. (2014) mentioned that some of the notions rooted in social life are favourable to the occurrence of violent interpersonal relationships, which they designate by cultural phenomenon. They add that the common actions and attitudes in adolescents, as for example the acceptance of the humiliation by the partner (or even of the physical and sexual aggression), have their origins in a culture that romanticises love, and naturalises the feeling of possession or jealousy.

Therefore, this study adds significant knowledge to the current context of the phenomenon of dating violence, which may contribute to future actions aimed at the development of healthy social skills, which are essential for the adolescents' future.

This study sought to add some knowledge based on epidemiological data from dating violence. For being a cross-sectional study, the characteristics presented here refer to a specific period of time and may undergo some changes as interventions are implemented.

\section{Conclusion}

The results of this study indicate that adolescents are both perpetrators and victims in their dating relationships and that the rate of victimisation is higher among males, which is not in line with most of the literature. The high prevalence of this problem is associated with its naturalisation, suggesting that violence is a normal part of the dating relationships, which corroborates the hypothesis of this study. No significant association was found between dating violence and the adolescents' age range. Future studies should explore the reasons for the adolescents' behaviours in their dating relationships, in order to obtain information that allow closely following this phenomenon and understanding it better. In this way, it will be possible to plan preventive actions that can eradicate this phenomenon and minimise the consequences of dating violence for the adolescents.

Acknowledgements: This study is part of the activities planned for the Sandwich Doctorate scholarship and had the support of the Coordination for the Improvement of Higher Education Personnel - CAPES, a Foundation of the Ministry of Education in Brazil.

\section{References}

Aldrighi, T. (2004). Prevalência e cronicidade da violência física no namoro entre jovens universitários do estado de São Paulo, Brasil. Psicologia: Teoria e Prática, 6, 105-120.

Barreira, A., Lima, M., \& Avanci, J. (2013). Coocorrência de violência física e psicológica entre adolescentes namorados do Recife, Brasil: Prevalência e fatores associados. Ciência E Saúde Coletiva, 18(1), 233-243. Retrieved from http:// dx.doi.org/10.1590/S1413-81232013000100024

Barreira, A., Lima, M., Bigras, M., Njaine, K., \& Assi, S. (2014). Direcionalidade da violência física e psicológica no namoro entre adolescentes do Recife, Brasil. Revista

Brasileira de Epidemiologia, 17(1), 217-228. Retrieved from http://dx.doi.org/10.1590/1415-790X201400010017ENG

Basile, K. C., Black, M. C., Simon, T. R., Arias, I., Brener, N. D., \& Saltzman, L. E. (2006). The association between self-reported lifetime history of forced sexual intercourse and recent health-risk behaviors: Findings from the 2003 national youth risk behavior survey. Journal of Adolescent Health, 39(5), 752 . 
Bonomi, A., Anderson, M., Nemeth, J., Rivara, F., \& Buettner, C. (2014). History of dating violence and the association with late adolescent health. BMC Public Health, 13, 821. doi:10.1186/1471-2458-13-821

Centers for Disease Control and Prevention. (2014). Understanding teen dating violence. Retrieved from http://www.cdc.gov/ violenceprevention/pdf/teen-dating-violence-2014-a.pdf

Foshee, V., Reyes, H., Gottfredson, N., Chang, LY, \& Ennett, S. (2013). A longitudinal examination of psychological, behavioral, academic, and relationship consequences of dating abuse victimization among a primarily rural sample of adolescents. Journal of Adolescent Health, 53(6), 723-729. doi: http://dx.doi.org/10.1016/j.jadohealth.2013.06.016

Freire, I., Simão, A., \& Ferreira, A. (2006). O estudo da violência entre pares no $3^{\circ}$ ciclo do ensino básico: Um questionário aferido para a população escolar portuguesa. Revista Portuguesa de Educação, 19(2), 157-183.

Haynie, D., Farhat, T., Brooks-Russel, A., Wang, J., Barbieri, B., \& Iannotti, R. (2013). Dating violence perpetration and victimization among US adolescents: Prevalence, patterns, and associations with health complaints and substance use. Journal of Adolescent Health, 53(2), 194-201.

Heise, L., \& Garcia-Moreno, C. (2002). Violence by intimate partners. In E. Krug, L. Dahlberg, J. Mercy, A. Zwi, \& R. Lozano (Eds.), World report on violence and bealth

(pp. 87-121). Geneva, Switzerland: World Health Organization.

Leitão, M. N., Fernandes, M. I., Fabião, J. S., Sá, M. C., Veríssimo, C. M., \& Dixe, M. A. (2013). Prevenir a violência no namoro: N(Amor)O (Im)Perfeito: Fazer diferente para fazer a diferença. Coimbra, Portugal: Escola Superior de Enfermagem de Coimbra; Unidade de Investigação em Ciências da Saúde: Enfermagem.
Minayo, M., Assis, S., \& Njaine, K. (2011). Amor e violência: Um paradoxo das relações de namoro e do 'ficar' entre jovens brasileiros. Rio de Janeiro, Brasil: Fiocruz.

Oliveira, Q., Assis, S., Njaine, K., \& Carvalhaes, R. (2011).Violência nas relações afetivo-sexuais. In M. Minayo, S. Assis, \& K. Njaine (Eds), Amor e violência: Um paradoxo das relações de namoro e do 'ficar' entre jovens brasileiros (pp. 87-151). Rio de Janeiro, Brasil: Fiocruz.

Oliveira, Q., Assis, S., Njaine, K., \& Pires, T. (2014). Namoro na adolescência no Brasil: Circularidade da violência psicológica nos diferentes contextos relacionais. Ciência \& Saúde Coletiva, 19(3), 707-718. Retrieved from http://dx.doi. org/10.1590/1413-81232014193.19052013

World Health Organization (2012). Global school-based student bealth survey. Retrieved from http://www.who.int/chp/ gshs/en/

Ozella, S., \& Aguiar, W. M. (2008) Desmistificando a concepção de adolescência. Cadernos de Pesquisa, 38(133), 97-125. Retrieved from http://www.scielo.br/pdf/cp/v38n133/ a05v38n133.pdf.

Ruzany, M. H. (2008). Atenção à saúde do adolescente: Mudança de paradigma. In Ministério da Saúde (Ed.), Saúde do adolescente: Competências e babilidades (pp. 21-27). Brasília, Brasil: Autor.

Straus, M. (2004). Prevalence of violence against dating partners by male and female university students worldwide. Violence Against Women, 10(7), 790-811.

Straus, M., \& Gozjolko, K. (2014). "Intimate terrorism" and gender differences in injury of dating partners by male and female university students. Journal of Family Violence, 29(1), 51-65.

World Health Organization (2015). Adolescent health. Retrieved from http://www.who.int/topics/adolescent_health/en/ 
